\title{
No changes in Northern Vietnam's precipitation extremes during rainy season for the time period from 1975 to 2006
}

\author{
Không có sự thay đổi về các đợt mưa cực đoan vào mùa mưa ở miền Bắc Việt Nam trong \\ khoảng thời gian từ 1975 đến 2006
}

\section{Sebastian GOIHL}

Formerly at Geography Institute, Georg-August-University Göttingen, Goldschmidtstr. 3, Göttingen, Germany

\begin{abstract}
A consequence of climate change may be higher frequencies and higher intensities of extreme climate events all over the world. This paper takes a closer look at the Northern Vietnam climate conditions. The area of interest are the geographical regions North East, North West, Red River Delta and North Central Coast. For research of extreme climate, the data from 72 meteorological stations for the time period from 1975 to 2006 were used and tested for the rainy season with the method of indices for climate change research created by Expert Team on Climate Change Detection (ETCCDI). Apparently, there is a linkage between the indices and topics of social and economic impacts, but this is not a clear fact. The climate change and extreme precipitation indices of the annual total precipitation above the 95th percentile (R95p), the annual total precipitation above the 99th percentile (R99p), the simple precipitation intensity amount (SDII), the annual total precipitation on wet days (PRCPTOT) and a modified annual total precipitation above $50 \mathrm{~mm}$ (R50mm) are used in this study. The question, whether there are statistically significant trends is answered using the Mann-Kendall Trend test. The results show that the indices are strongly influenced by the variations of the Vietnamese climate. Hence many stations have no significant trends. For the investigated time period, most of significance trends were decreasing. But there is a positive correlation between the total precipitation in the rainy season (PRCPTOT) and the frequencies of extreme climate events above the indices thresholds from R95p and R99p. Concluding, climate models show that higher total precipitations are likely for the area of interest. Therefore, it can be expected that, in a changing climate, more extreme climate events with higher intensities will occur.
\end{abstract}

Biến đổi khí hậu có thể dẫn đến sự gia tăng về tần số và cường độ của các hiện tượng thời tiết cực đoan trên toàn thế giới. Nghiên cứu này sẽ xem xét kỹ hơn về các điều kiện khí hậu ở miền Bắc Việt Nam. Địa điểm nghiên cứu bao gồm các khu vực địa lý Đông Bắc, Tây Bắc, Đồng bằng sông Hồng và Bắc Trung Bộ. Đểnghiên cứu về khí hậu cực đoan, các dữ liệu trong khoảng thời gian từ 1975 đến 2006 đã được thu thập từ 72 trạm khí tượng. Những dữ liệu này được dùng để kiểm chứng đối với mùa mưa theo phương pháp chỉ số nghiên cứu biến đổi khí hậu của Nhóm chuyên gia về phát hiện biến đổi khí hậu (ETCCCDI). Hiển nhiên có một mối liên hệ giữa các chỉ số với các chủ đề về tác động kinh tế và xã hội, tuy nhiên thực tế này vẫn chưa rõ ràng. Các chỉ số biến đổi khí hậu và mưa cực đoan của tổng mưa hằng năm trên 95 phần trăm (R95p), tổng mưa hằng năm trên 99 phần trăm (R99p), chi số cường độ mưa trên ngày (SDII), tổng mưa hằng năm vào những ngày ẩm ướt - mùa mưa (PRCPTOT) và tổng mưa hằng năm biến đổi trên $50 \mathrm{~mm}(R 50 \mathrm{~mm})$ được sử dụng trong nghiên cứu này. Câu hỏi về sự tồn tại của các xu hướng quan trọng về mặt thống kê được trả lời bằng phương pháp Mann-Kendall Trend. Các kết quả chỉ ra rằng các chi số chịu ảnh hưởng lớn từ sự biến đổi của khí hậu Việt Nam. Do vậy, ở một số trạm khí tượng không có các xu hướng có ý nghĩa. Trong khoảng thời gian nghiên cứu, các xu hướng quan trọng đều giảm. Tuy nhiên, có một mối tương quan thuận giữa tổng lượng mưa trong mùa mưa (PRCPTOT) và cường độ của các hiện tượng thời tiết cực đoan trên các cực của chi số từ R95P và R99p. Kết luận, các mô hình thời tiết cho thấy tổng lượng mưa lớn hơn có khả năng sẽ xảy ra trên địa bàn nghiên cứu. Vi vậy, có thể phỏng đoán rằng khi thay đổi khí hậu, sẽ diễn ra nhiều hiện tượng thời tiết cực đoan với cường độ cao.

Keywords: climate extreme indices, precipitation extremes, ETCCDI, Northern Vietnam, rainy season

\section{Introduction}

Climate change causes a heated atmosphere which can gather more water. As an effect, local and regional precipitation regimes may change (Nicholls et al., 1996). As important as climate change the alternation of extreme weather is one of the major flood inducing factors because it shows directly impacts on variability and availability of hazardous amount of water (Hong et al., 2014). For measuring the development of climate extremes, indices were established. According to Zhang et al. (2011) indices are a significant step forward to understand, whether climate becomes more variable or extreme. There are 27 so called core indices after ETCCDI (2016), 11 for measuring precipitation and the remaining 16 for temperature research. 
The indices are used for detection and monitoring of climate change. So, increasing and decreasing trends of the index-values can be used as evidence of change. They enable us to describe how strong and how quickly the change takes place. The calculation of a time series is important for this study to reflect the development the indices of recent years. But increasing fluctuations can also be an indication of climate change.

Apart from the indices developed by the ETCCDI, other indices have been developed, a number of them are overlapping with the ETCCDI ones and several new indices were modified from ETCCDI indices (Zhang et al., 2011). Research on climate extremes has a long indices-based history and surely it is connected with advantages in understanding climate change.

Many authors see a link between the results of indices measurement and ecological, economic and social impacts on the society (Aguilar et al., 2009; Caesar et al., 2011; Caloiero, 2014; Ducic et al., 2012; Manton et al., 2001; Quan et al., 2013; Zwiers et al., 2013). But such linkages were not detailed described and the linkage mechanism are not clearly defined.

It is not easy to define heavy or extreme rainfall. There are many definitions, but at this place it cannot ultimately be determined which definition is the most exact. So, talking about extremes remains imprecise (Alexander, 2015). A threshold is needed, by which normal rainfall can be differentiated from heavy or extreme rainfall based on the rainfall intensity. The thresholds are often defined by using percentiles (Ranke, 2015). If the accumulated precipitation is higher than the threshold value, this rainfall event is one of the heavy or extreme ones. As has been said before, different percentiles have been used to describe extremes. For example, Kundzewicz and Schellnhuber (2004) define heavy by the 99th percentile of the daily totals. Haylock et al. (2006) called the 95th percentile as threshold for very wet day precipitation and above the 99th percentile, they defined it as extremely wet day precipitation. Chang \& Kwon (2007) define the 90th percentile as threshold for heavy precipitation events. Karl and Knight (1998) called events above the same percentile value as very heavy precipitation events. Ho et al. (2011) describe heavy rainfall days as days above the 95th percentile of accumulated precipitation on rainy days. As shown the definitions are not consistent and differ often in linguistic nuances.

This study aims to investigate if there are trends in precipitation extremes for the area of interest in Northern Vietnam, which covers the gap in detailed investigations. New research concerning this question is recommended to initiate useful steps of natural hazard management in a region endangered by floods and flash floods.

\subsection{Status of climate extreme research}

Precipitation extremes were examined in regional studies. However, there not many studies available for the indo-pacific region, which covers northern Vietnam. From them, only a few studies analyze Vietnam's precipitation patterns in particular. In these studies, climate extreme indices are used often. For a better understanding of the following lines, see table 1. Another source for climate research data are online datasets hosted on websites like CLIMDEX (https://www.climdex.org/). For the indo-pacific region, Ceasar et al. (2011) have claimed that spatial coherence in precipitation indices is missing and that there is a low number of stations with significant trends. Endo et al. (2009) stated that the northern Vietnam's annual rainfall and the rainfall intensity of the $\mathrm{R} 95 \mathrm{p}$ index are decreasing since the 1950s. In this study 200 weather stations were studied all over the pacific region, but the number of significant trends was low and reach for all indices maximum 10\%. Choi et al. (2009) calculate a decreasing of $44.2 \mathrm{~mm}$ per decade from the annual rainfall amount. But this calculation was not significant, as the authors underline. In this study, significant trends reach 10 to $14 \%$ depending on the different indices. Manton et al. (2001) claimed, that for the majority of stations in the whole region extreme rainfall events have declined.

Yazid and Humphries (2015) took a closer look on Vietnam when they researched eight precipitation indices of the Indochina peninsula. For Hanoi city, the indices were decreasing. As in other studies, significant results only reach 20 till 30\%. Quan et al. (2013) detected strong variations for R50mm and R99p too. The R50mm seems to have a negative trend, meanwhile the R99p have strong fluctuations. They identified that trends in the northern part of Vietnam are generally weaker as in the south. Ngu-Duc (2014) stated that rainfall in the northern coastal areas from $17^{\circ} \mathrm{N}$ northward is decreasing for the winter, summer and autumn seasons. However, the World Bank (2011) indicates that there is no statistical trend in the mean rainfall over Vietnam since 1960.

\subsection{Study area}

To clarify all these questions about the development of extreme precipitation for Vietnam and to ensure a resourceefficient detailed analysis, the study area was limited to the northern part of the country. Four northern Vietnam geographical regions constitute the study area: North West, North East, Red River Delta and North Central Coast. The area size is nearly $191.000 \mathrm{~km}^{2}$ and the topography reaches from high mountainous areas over hilly landscapes to flat delta and coastal areas. The highest mountains of the country are located in the North West. The climate is determined by the monsoon. The year can be divided into two phases by climate conditions, a hot and wet phase and a warm and dry phase. These parts are called wet season and dry season. There are strong differences 
between the rainfall intensity in the different geographical regions (Tuyen, 2005).

\subsection{Wet season - definition}

The maximum of yearly rainfall is accumulated during the wet season. The dimension of this accumulation is 70 to $80 \%$. The spatial and temporal settings of this wet season cannot be simplified, because the wet season delays from North to South (Imamura \& To, 1997; Tuyen, 2005). Moreover, the rainfall accumulation depends on the occurrence of tropical cyclones. However, there is a lot of imprecise information about, when and where the wet season starts or ends. Nguyen et al. (2014) set the duration of the wet season in the North for the months May to October and for the Central region for August to September. Chang et al. (2005) said, that for all regions north of $10^{\circ} \mathrm{N}$ the duration of the wet season is July to October. The flood season, which is connected to the rainy season, starts in Northern Vietnam in May/June and ends in September or October (World Bank, 2010). A study on the Son La province in the region North West determines the rainy season for the time period from April to September (Schad et al., 2012).

As it can be seen, a clear definition for the wet season is missing. To solve this problem, a definition by the Institute of Strategy and Policy on Natural Resources and Environment (ISPONRE) Vietnam (2009) was used here, which defines, with a clear threshold, the rainy season "as the time when the monthly average rainfall is over $100 \mathrm{~mm}$ ". Following this definition, the individual wet seasons for each weather station used in this study were calculated by the monthly means for the investigation period.

\section{Table 1. Used indices after ETCCDI}

\begin{tabular}{lll} 
Index & Indicator name & Definitions \\
\hline R95p & Very wet day precipitation & Annual total precipitation when RR $\geq 95$ percentile for the time period \\
& & $1975-2006$ \\
R99p & Extremely wet day precipitation & Annual total precipitation when RR $\geq 99$ percentile for the time period \\
& & $1975-2006$ \\
SDII & Simple daily intensity index & Average precipitation from wet days \\
PRCTOT & Wet-day precipitation & Annual total precipitation from wet days \\
R50mm & Heavy annual precipitation & Annual total precipitation from days when RR $\geq 50 \mathrm{~mm}$
\end{tabular}

\section{Material and methods}

The dataset used here was obtained from Vietnam's Hydrometeorological Data Center. The data is hosted at the World Bank website: https://datacatalog.worldbank. org/dataset/wps5491-rainfall-data-172-weather-stationsvietnam. The time period of the dataset is mostly from 1975 to 2006. According to this present dataset, there are 172 meteorological stations in Vietnam. Another 78 stations are no longer in operation, but are contained within this data set. For this study, the data of 72 stations were used because they cover the study area. The North West is represented by 15 stations, the North East and the North Central Coast by each 22 and 13 stations covers the Red River Delta. The data format is Excel tables and contains spatial locations and daily precipitation data in one table, sorted by years and days in the rows and months in the columns.

For the calculation of indices high quality and high frequency homogeneous meteorological data is required (Zwiers et al., 2013). The used datasets are in daily resolution and therefore have an adequate frequency. Since the source is an official meteorological service it could be assumed that the data have a good quality. However, quality control shows that there are some problems with this dataset. The quality control in this study is a two-step process. First, stations with data gaps of more than a year are sorted out. The remaining datasets have some gaps from one or two months. These gaps are filled with the mean daily data from stations from the same region of the rainy season.

To fill the gaps, the required mean values were calculated and inserted into them. 14 of 72 stations have this kind of monthly data gaps. Overall 23 months of data record are missing, which compiles a missing rate of $0.18 \%$ from the total data recorded.

There had to be further adjustments to the raw data. By scientific convention for analyzing indices there is a differentiation between rainy days and dry days. A rainy day is a day with precipitation of more than $1 \mathrm{~mm}$. In the dataset precipitation days with more than zero millimeter rainfall but less than one millimeter are declare with $0 \mathrm{~mm}$. These days are sorted out.

The Expert Team on Climate Change Detection (ETCCDI) considered 27 indices on Climate Change as core indices. Eleven of them deal with precipitation. This study is limited to precipitation extremes, so not all of these 27 indices need to be used. Instead, it focuses on key precipitationbased indices. The used climate change and extreme precipitation indices are R95p, R99p, SDII, PRCPTOT and a modified R50mm (Table 1). The R50 mm is modified, because it is originally the Rnnmm index, which allows the usage of a user defined threshold and counts the days above it. In this study, however, the precipitation totals are summed above the threshold of $50 \mathrm{~mm}$ as in the percentile-based indices. 
The thresholds for the percentile-based indices are calculated for the yearly rain seasons dataset time series 1975 to 2006. As a result, the 32 annual time series for each index and from every station is trend tested with the MannKendall rank correlation test. This test shows the direction and the statistical significance for each station as the investigated time period. Additionally, the regional trends are examined by using the Mann-Kendall rank correlation test for direction and significance and regression analysis for the trend strength. The regional value is calculated by the rainy season means from each station. In this study, three significant levels are used by $a<=0.1, a<=0.05$ and $a<=$ 0.01 .

\section{Results}

The precipitation indices do not show significant trends for the variety of stations. The range of non-significant station trends reaches from $65 \%$ at the SDII to $81 \%$ at the PRCPTOT. Negative trends are, at a low level, twice to four times more frequent than positive trends. Overall, only 10 to 19 of the 72 weather stations show a significant negative trend depending on the index studied. The rate of stations with positive trends is still lower and affected by absolute values. A closer look on Figure 2 shows as an example of the trends of the R99p index at the considered meteorological stations.

At the regional scale (Table 2), the rate of change per decade for most regions is negative. There is a strong variation over the investigated time period, as presented in Figure 1. There are only weak increments in the North West. Strong declines are calculated for the Red River Delta and the North Central Coast. In this region, the annual total precipitation PRCPTOT declines more than $40 \mathrm{~mm}$ in rainy season per decade. The index SDII reaches even a decrease of
$56 \mathrm{~mm}$ per decade in rainy season at the Red River Delta. Moreover, three of five indices in the Red River Delta are significant. It must be pointed out that there are strong regional disparities in the annual total precipitation. So, the relative declines might be smaller for regions like the North Central Coast. To conclude, there are only a few indices with significant trends after the regional analysis. There are strong variations in each index time series, so the computing of statistically significant trends is difficult.

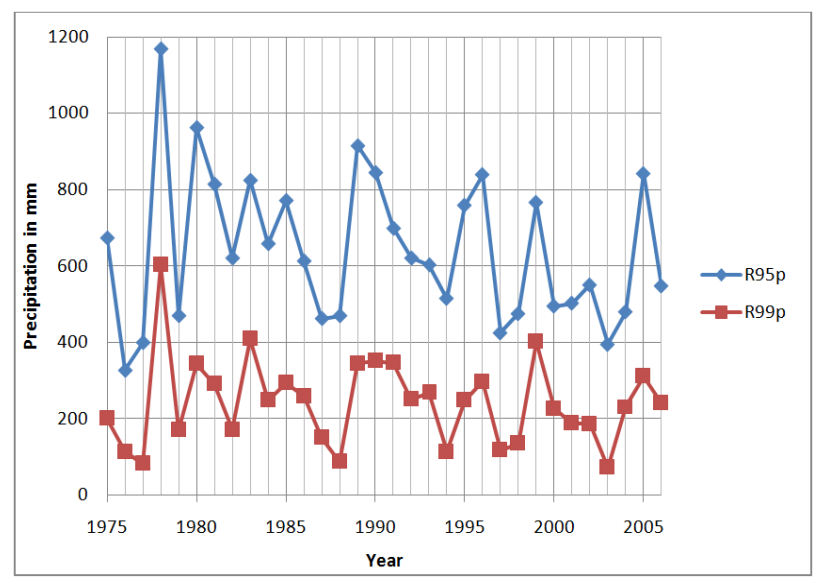

Figure 1. Time series of the indices R95p and R99p at the region North Central Coast.

Another approach is the analysis of the correlation coefficient. Nearly 2000 annual records of the stations were checked for correlation. In detail, the dependencies between the total precipitation and the indices R95p and R99p were tested. The test showed a correlation coefficient of $r^{2}=0.73$ between PRCTOT and R95p and $r^{2}=0.47$ between PRCTOT and R99p. These values are within the expected range because climatic events are often determined by a variety of variables.

Table 2. Regional trends after ETCCDI for Northern Vietnam during rainy season

\begin{tabular}{|c|c|c|c|c|c|}
\hline Index/Region & North West & North East & Red River Delta & North Central Coast & $1975-2006$ \\
\hline R95p & 7.8 & -17.5 & -42.2 & -43.52 & $\mathrm{~mm} /$ decade \\
\hline R99p & 1.63 & -8.8 & $-32.5^{\star}$ & -14.57 & $\mathrm{~mm} /$ decade \\
\hline SDII & $0.21+$ & -0.4 & -0.42 & $-0.63^{\star}$ & $\mathrm{mm} /$ decade \\
\hline PRCPTOT & 4.86 & -34.5 & $-48.3+$ & -40.35 & $\mathrm{~mm} / \mathrm{dec} a d e$ \\
\hline $\mathrm{R} 50 \mathrm{~mm}$ & 9.94 & -19.6 & $-55.9+$ & -39.85 & $\mathrm{~mm} /$ decade \\
\hline
\end{tabular}

Symbols: + for trends at $\alpha \leq 0.1$ significance level, * for trends at $\alpha \leq 0.05$ significance level. 


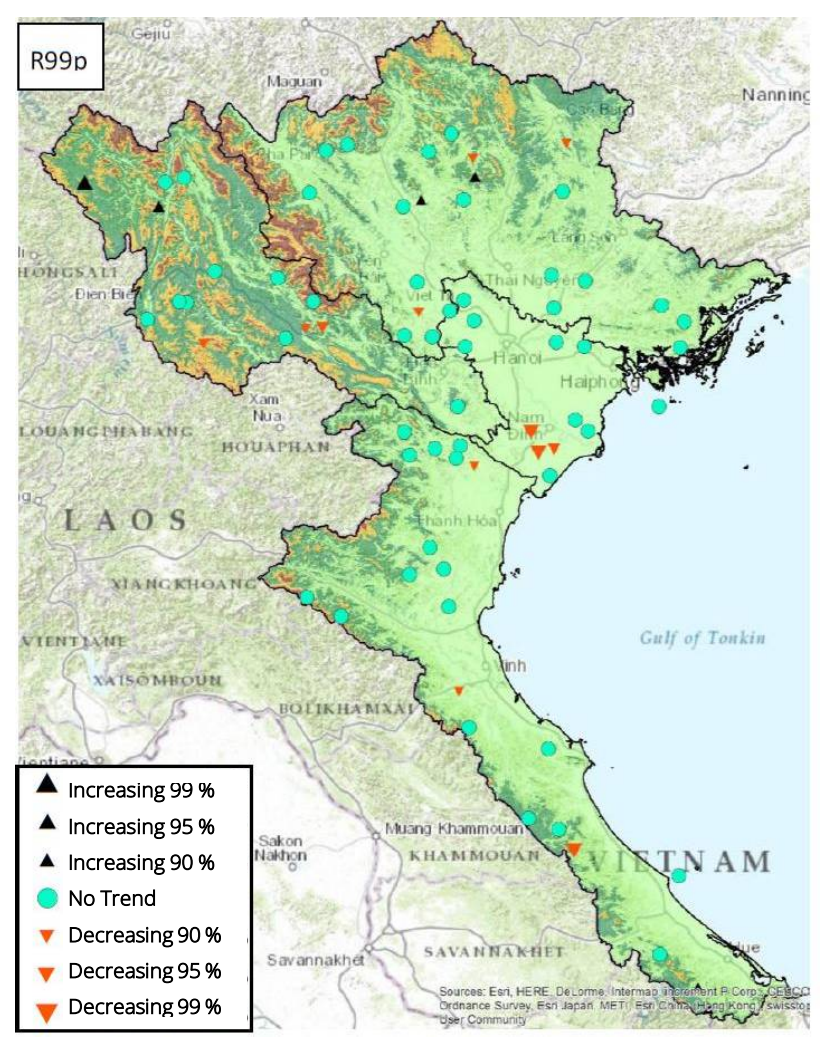

Figure 2. Stations and trends of the R99p-index in Northern Vietnam at the rain season. Sources: Topographic Basemap by ESRI (2016) \& SRTM Elevation Model by USGS (2016).

\section{Discussion}

The results of this study are in line with the existing studies on climate extremes. Therefore, it is not surprising that there are so many non-significant trends. This study confirms previous study results and shows that the northern part of Vietnam is not affected by strong trends. For all five investigated indices, spatial patterns could not be found.

The Indices after ETCCDI might be highly recommended, but in fact, the statistical thresholds can be called arbitrary. All results beneath the thresholds of statistical significance are categorized as No Trend. This might be an oversimplification of a complex topic. Alternatively, a closer look at the Mann-Kendall-S-value can be helpful. The S-value is an important value to measure the strength of a trend, because it adds up or subtracts the value 1 to the S-value consequent upon the subsequent data values in a time period. For this case, as an example for the R50mm, two out of three meteorological stations have a negative S-value. In short, the result depends on the preferences in the study design. On the one hand, the usage of S-values that is appropriate to each station comparable values have got more information, on the other hand most of them are not significant.

\section{Conclusions}

No indications have been generated by the present study to prove that climate change has affected extreme precipitation events in northern part of Vietnam over the time period from 1975 to 2006. Only a small proportion of weather stations show significantly positive or negative trends for the studied indices. The spatial distribution of these stations also allows no conclusions about local clusters. With the exception of the Red River Delta, there is little evidence of change on a regional level. This leads to the conclusion that the impacts of climate change on the data used are either not reproducible or that there are no measurable impacts.

Decreasing rainfall suggests a theoretical decrease of the heavy rain regime due to the correlation with the R95p index. However, decreasing rainfall is not significant except for the Red River Delta. Unfortunately, in a changing climate system, this does not provide reassurance, as evidenced by the steady loss of life as a result of heavy raininduced natural hazards.

Despite these study results, there is still a need for monitoring precipitation extremes. This is due to the fact that many natural hazards are caused by precipitation. Climate change is taking place more and more intensely, as a result of which the atmospheric influence over the study area has also increased. This illustrates the need for monitoring, as otherwise potentially important turning points in development may be missed.

Further research on this specific topic is needed to understand the correlation between climate change and precipitation extremes. For this purpose, current time series should be used, as well as the methods of remote sensing, such as areal recordings by radar data.

Acknowledgement: The author would like to thank you Dr. Jan Degener and Prof. Martin Kappas for supervising this master thesis, the results of which have been presented in this research paper.

\section{References}

[1] Alexander, V. (2015) Global observed long-term changes in temperature and precipitation extremes: A review of progress and limitations in IPCC assessments and beyond. Weather and Climate Extremes. doi:10.1016/j.wace.2015.10.007.x.

[2] Aguilar, E., Aziz Barry, A., Brunet, M., Ekang, L., Fernandes, A., Massoukina, M., Mbah, J., Mhanda, A., do Nascimento, D. J., Peterson, T. C., Thamba Umba, O., Tomou, M., Zhang, X. (2009) Changes in temperature and precipitation extremes in western central Africa, Guinea Conakry, and Zimbabwe, 19552006. Journal of Geophysical Research, 114. doi:10.1029/2008JD011010. 
[3] Caesar, J., Alexander, L. V., Trewin, B., Tse-ring, K., Sorany, L., Vuniyayawa, V., Keosavang, N., Shimana, A., Htay, M. M., Karmacharya, J., Jayasinghearachchi, D. A., Sakkamart, J., Soares, E., Hung, L. T., Thuong, L. T., Hue, C. T., Dung, N. T. T., Hung, P. V., Cuong, H. D., Cuong, N. M., Sirabaha, S. (2011) Changes in temperature and precipitation extremes over the Indo-Pacific region from 1971 to 2005. International Journal of Climatology 31: 791-801.

[4] Caloiero, T. (2014) Analysis of daily rainfall concentration in New Zealand. Natural Hazards 72: 389-404.

[5] Chang, C.-P., Wang, Z., McBride, J., Liu C.-H. (2005) Annual Cycle of Southeast Asia - Maritime Continent Rainfall and the Asymmetric Monsoon Transition. Journal of Climate 18: 287-301.

[6] Chang, H., Kwon, W.-T. (2007) Spatial variations of summer precipitation trends in South Korea, 19732005. Environmental Research Letters 2(4), 045012.

[7] Choi, G., Collins, D., Ren, G., Trewin, B., Baldi, M., Fukuda, Y., Afzaal, M., Pianmana, T., Gomboluudev, P., Huong, P. T. T., Lias, N., Kwon, W.-T., Boo, K.-O., Cha, Y.-M., Zhou Y. (2009) Changes in means and extreme events of temperature and precipitation in the AsiaPacific Network region, 1955-2007. International Journal of Climatology 29: 1906-1925.

[8] Ducić, V., Luković, J., Burić, D., Stanojević, G., Mustafić, S. (2012) Precipitation extremes in the wettest Mediterranean region (Krivošije) and associated atmospheric circulation types. Natural Hazards and Earth System Sciences 12: 687-697.

[9] Endo, N., Matsumoto, J., Lwin, T. (2009) Trends in Precipitation Extremes over Southeast Asia. Scientific Online Letters on Atmosphere 5: 168-171.

[10] ESRI (2016) "Topographic" [basemap]. Scale Not Given. "World Topographic Map". April 21, 2016. http://www.arcgis.com/home/item.html?id=30e5fe31 49c34df1 ba922e6f5bbf808f.

[11] ETCCDI (2015) Climate Change Indices. Definitions of the 27 core indices. http://etccdi.pacificclimate.org/list_27_indices.shtml.

[12] Haylock, M. R., Peterson, T. C., Alves, L. M., Ambrizzi, T., Anunciação, Y. M. T., Baez, J., Barros, V. R., Berlato, M. A., Bidegain, M., Coronel, G., Corradi, V., Garcia, V. J., Grimm, A. M., Karoly, D., Marengo, J. A., Marino, M. B., Moncunill, D. F., Nechet, D., Quintana, J., Rebello, E., Rusticucci, M., Santos, J. L., Trebejo, I., Vincent L. A. (2006) Trends in Total and Extreme South American Rainfall in 1960-2000 and Links with Sea Surface Temperature. Journal of Climate. 19: 1490-1512.

[13] Ho, T.-M.-H., Phan, V.-T., Le, N.-Q., Nguyen, Q.-T. (2011) Extreme climatic events over Vietnam from observational data and RegCM3 projections. Climate Research 49: 87-100

[14] Hong, Y., Liu, L., Qiao, L., Aahikari, P. (2014) Climate
Change and Hydrological Hazards. In: Eslamian, S. (Ed.): Handbook of Engineering Hydrology: Fundamentals and Applications. Boca Raton. pp.54-70.

[15] Imamura, F., To, D. V. (1997) Flood and Typhoon Disasters in Viet Nam in the Half Century Since 1950. Natural Hazards 15: 71-87.

[16] ISPONRE (2009) Viet Nam Assessment Report on Climate Change (VARCC). Institute of Strategy and Policy on Natural Resources and Environment. Hanoi. Vietnam.

[17] Karl, R. K., Knight R. W. (1998) Secular Trends of Precipitation Amount, Frequency, and Intensity in the United States. Bulletin of the American Meteorological Society 79: 231-241.

[18] Kundzewicz Z. W., Schellnhuber H.-J. (2004) Floods in the IPPC TAR perspective. Natural Hazards 31: 111128.

[19] Manton, M.J., Della-Marta, P.M., Haylock, M.R., Hennessy, K.J., Nicholls, N., Chambers, L.E., Collins, D.A., Daw, G., Finet, A., Gunawan, D., Inape, K., Isobe, H., Kestin, T.S., Lefale, P., Leyu, C.H., Lwin, T., Maitrepierre, L., Ouprasitwong, N., Page, C.M., Pahalad, J., Plummer, N., Salinger, M.J., Suppiah, R., Tran, V.L., Trewin, B., Tibig, I., Yee, D. (2001) Trends in extreme daily rainfall and temperature in Southeast Asia and the South Pacific: 1961-1998. International Journal of Climatology 21: $269-284$.

[20] Ngu-Duc, T. (2014) Climate Change in the Coastal Regions of Vietnam. In: Thoa, N. D., Takagi, H., Esteban, M. (Ed.): Coastal Disasters and Climate Change in Vietnam. London. Great Britain. pp.173-198.

[21] Nguyen, K. C., Katzfey, J. J., McGregor, J. L. (2014) Downscaling over Vietnam using the stretched-grid CCAM: verification of the mean and interannual variability of rainfall. Climate Dynamics 43: 861-879.

[22] Nicholls, N., Gruza, G. V., Jouzel, J., Karl, T. R., Ogallo, L. A., Parker, D. E. (1996) Observed climate variability and change - in Houghton, J. T., Meira Filho, L. G., Callander, B. A., Harris, N., Kattenberg, A., Maskell, K. (Ed.): Climate Change 1995. The Science of Climate Change. Cambridge. pp.133-192.

[23] Quan, L.-N., Tan, P.-V., Trung, N.-Q., Thanh, N.-D. (2013) Trends in Extreme Rainfall Events over Vietnam: Historical Data and Model Verification. The Third International MAHASRI/HyARC Workshop on Asian Monsoon and Water Cycle. Da Nang. pp.209216.

[24] Ranke, U. (2015) Natural Disaster Risk Management. Geosciences and Social Responsibility. Springer International Publishing, Heidelberg. Germany. ISBN: 9783-319-20674-5 (hardcover).

[25] Schad, I., Schmitter, P., Saint-Macary, C., Neef, A., Lamers, M., Nguyen, L., Hilger, T., Hoffmann, V. (2012) 
Why do people not learn from flood disasters? Evidence from Vietnam's northwestern mountains. Natural Hazards 62: 221-241.

[26] World Bank (2010) Weathering the Storm: Options for Disaster Risk Financing in Vietnam. Washington DC. United States of America.

[27] World Bank (2011) Vulnerability, Risk Reduction, and Adaption to Climate Change. Vietnam. Washington DC. United States of America.

[28] Tuyen, H. M. (2005) Zoning Rainfall Intensity of Vietnam. Asian Pacific FRIEND. Intensity Frequency Duration and Flood Frequencies Determination Meeting, Kuala Lumpur, Malaysia, 6-7 June 2005, p.33.

[29] Yazid, M., Humphries U. (2015): Regional Observed Trends in Daily Rainfall Indices of Extremes over the
Indochina Peninsula from 1960 to 2007. Climate 3: 168-192.

[30] Zhang, X., Alexander, L.V., Hegerl, G. C., Jones, P., Klein Tank, A., Peterson, T. C., Trewin, B., Zwiers F. W. (2011) Indices for monitoring changes in extremes based on daily temperature and precipitation data. WIREs Climate Change 2: 851-870.

[31] Zwiers, F.W., Alexander, L.V., Hegerl, G.C., Knutson, T.R., Kossin, J.P., Naveau, P., Nicholls, N., Schär, C., Seneviratne, I., Zhang X. (2013) Climate Extremes: Challenges in Estimating and Understanding Recent Changes in the Frequency and Intensity of Extreme Climate and Weather Events. - in: Asrar, G.R. \& J.W. Hurrell (Ed.): Climate Science for Serving Society. Research, Modeling and Prediction Priorities. 339-389. 